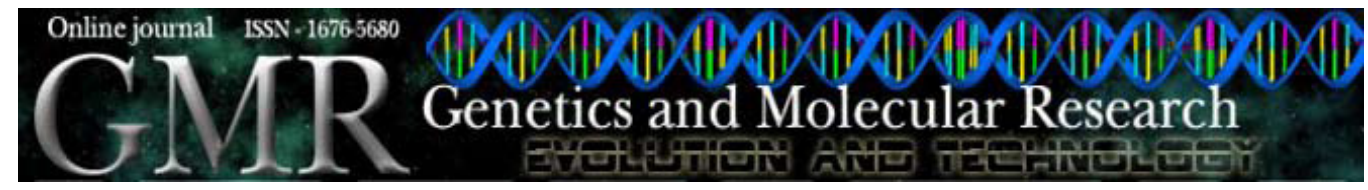

\title{
Analysis of protein expression and a new prokaryotic expression system for goat (Capra hircus) spermadhesin Bdh-2 cDNA
}

\author{
J.B. Cajazeiras ${ }^{1}$, L.M. Melo ${ }^{1}$, E.S. Albuquerque ${ }^{1}$, G. Rádis-Baptista ${ }^{2}$, \\ B.S. Cavada ${ }^{3}$ and V.J.F. Freitas ${ }^{1}$ \\ ${ }^{1}$ Laboratório de Fisiologia e Controle da Reprodução, \\ Universidade Estadual do Ceará, Fortaleza, CE, Brasil \\ ${ }^{2}$ Instituto de Ciências do Mar, Labomar, Universidade Federal do Ceará, \\ Fortaleza, CE, Brasil \\ ${ }^{3}$ Laboratório de Moléculas Biologicamente Ativas, Biomol-Lab, \\ Universidade Federal do Ceará, Fortaleza, CE, Brasil \\ Corresponding author: V.J.F. Freitas \\ E-mail: vjff@pq.cnpq.br
}

Genet. Mol. Res. 8 (3): 1147-1157 (2009)

Received May 21, 2009

Accepted August 5, 2009

Published September 22, 2009

ABSTRACT. Low purification efficiency and incomplete characteriza-
tion of male goat (buck) spermadhesins (Bdhs) prompted us to develop
an effective system to produce recombinant Bdhs (rBdhs). Bdh- 2 cDNA
was inserted into a prokaryotic expression plasmid, pTrcHis TOPO.
The pTrcHis-Bdh-2 system was constructed to produce a His ${ }_{6}$ fusion
protein in Escherichia coli Top 10 cells. Recombinant clones were se-
lected by growth in ampicillin-enriched medium, PCR amplification
and nucleotide sequencing. The inserted cDNA was completely identi-
fied and recombinant protein synthesis was monitored by SDS-PAGE,
followed by immunoblotting with monoclonal anti-His antibody. Ex-
pression of insoluble rBdh-2 was achieved at 0.1 to $2.0 \mathrm{mM}$ IPTG, after
2 to $6 \mathrm{~h}$ of induction. Significantly increased production of rBdh-2 (P $<$
0.01 ) occurred with 1.5 mM IPTG after $2 \mathrm{~h}$ of induction, and with 0.3
mM IPTG after $4 \mathrm{~h}$ in culture. Among the induction times investigated,
a period of $6 \mathrm{~h}$ gave the lowest levels of rBdh-2 production; with a $6-\mathrm{h}$ 
incubation, there were no significant differences in $\mathrm{rBdh}-2$ production for the various concentrations of IPTG tested $(\mathrm{P}>0.05)$. The apparent molecular weight of rBdh-2 was $15.85 \pm 0.09 \mathrm{kDa}$, calculated by image analysis of membranes. This is similar to the theoretical molecular weight of $15.5 \mathrm{kDa}$ predicted from the nucleotide sequence. Prior to this study, expression of recombinant goat spermadhesin had never been reported. Thus, an effective prokaryotic rBdh-2 expression system was developed in order to provide an adequate tool for studying biofunctions of goat spermadhesins.

Key words: Capra hircus; Spermadhesin; Bodhesin; Recombinant protein; cDNA; Prokaryotic expression

\section{INTRODUCTION}

Spermadhesins are male secretory proteins that have so far been found in the seminal plasma of ungulates, being peripherally associated with the sperm surface (Reinert et al., 1996). They are a group of 12- to 16-kDa multifunctional polypeptides exhibiting a palette of ligand-binding affinities for oligosaccharides and sulfated polysaccharides such as heparin and also for serine protease inhibitor and phospholipids (reviewed in Töpfer-Petersen et al., 1998). These polypeptides are able to influence diverse reproductive functions, such as spermatozoa capacitation, acrosome stabilization, and sperm-oocyte fusion during the fertilization process (Töpfer-Petersen et al., 2008).

Spermadhesins have been characterized from boar (Calvete et al., 1995), stallion (Reinert et al., 1996), bull (Tedeschi et al., 2000), and ram (Bergeron et al., 2005) seminal plasma. In animals outside the ungulate order, neither spermadhesin proteins nor spermadhesin-specific transcripts have been detectable so far (Haase et al., 2005).

Previously, our group isolated and purified from seminal plasma and described the $\mathrm{N}$-terminal sequence and molecular mass of a protein structurally characterized as the first buck spermadhesin, referred to as buck seminal fluid protein or BSFP (Teixeira et al., 2002). BSFP has approximately $12 \mathrm{kDa}$ and shares $50 \%$ similarity with the swine spermadhesins AQN-1 and AWN. However, unlike the boar heparin-binding spermadhesins AQN-1, AQN-3 and AWN, BSFP is not able to bind heparin, resulting in low purification efficiency (Teixeira et al., 2006).

Only after the above proteins had been described, were some spermadhesin cDNAs cloned (Wempe et al., 1992; Kwok et al., 1993; Ekhlasi-Hundrieser et al., 2002; Melo et al., 2008). In two earlier studies, we cloned and characterized four cDNAs encoding the main isoforms of buck spermadhesins, collectively called Bodhesins or Bdhs (Melo et al., 2008, 2009). All deduced amino acid sequences contained the CUB domain signature of the spermadhesin family and were 49 to $52 \%$ similar to boar AWN. Among the four Bdh amino acid sequences, Bdh-2 was the most similar to the BSFP N-terminal fragment (Melo et al., 2008). After the investigation of the expression profile of Bdh genes in several tissues of the buck reproductive tract (seminal vesicle, testis, epididymis, bulbourethral gland, ductus deferens, and prostate) by real-time quantitative reverse transcriptase-polymerase chain reaction (qRT-PCR), we found that the seminal vesicle is the major site of Bdh production (Melo et al., 2009). 
Further experiments are necessary to characterize the particular function of each of these buck spermadhesins in order to improve our knowledge of reproductive mechanisms in this species. On the other hand, significant amounts of protein, depending on the protein size and experimental technique used, produced in a short time with reasonable cost efficiency, are required for various biology projects (Goulding and Perry, 2003).

The low purification efficiency and the incomplete characterization of Bdhs, as well as the potential multiplicity of biotechnological applications of proteins from the spermadhesin family, prompted us to establish an effective expression system to produce recombinant Bdhs. Escherichia coli is the preferred host for recombinant protein expression for various studies because it is rather easy to genetically manipulate, it is relatively inexpensive to culture, and expression is fast, typically producing protein in a single day (Peti and Page, 2007). Thus, in the present study, an effective prokaryotic recombinant Bdh-2 (rBdh-2) expression system was established in order to provide a solid basis for future functional studies and biotechnological applications of rBdhs.

\section{MATERIAL AND METHODS}

\section{Cloning of Bdh-2 cDNA}

cDNA coding for spermadhesin Bdh-2 was produced according to the method described by Melo et al. (2008). Briefly, total RNA was isolated from a single sexually mature buck of undefined breed using the Trizol reagent (Invitrogen, Carlsbad, CA, USA), following manufacturer instructions. Poly $\left(\mathrm{A}^{+}\right)$-RNA was obtained from total RNA by affinity chromatography on oligo(dT) cellulose, using an mRNA purification kit (Invitrogen). First-strand cDNA was synthesized by reverse transcription coupled to PCR using a 3'-adaptor-Oligo (dT)18 (Clontech, Montain View, CA, USA) and Moloney murine leukemia virus reverse transcriptase purchased from Promega (Madison, WI, USA). Following cDNA synthesis, the 3 '-rapid amplification of the cDNA end was performed. Cloning of the spermadhesin gene was performed with the pGEM-T Easy Vector System and E. coli JM109 (Promega). The identity of Bdh-2 cDNA was assessed by nucleotide sequencing performed on Mega BACE 750 DNA Analysis System (GE Healthcare, Piscataway, NJ, USA). The assembled cDNA sequence of Bdh-2 clones spanned 607 bp (GenBank accession number EF157969).

\section{Construction of prokaryotic expression vector}

The coding region of Bdh-2 was amplified by PCR using as template the pGEM-T Easy cloning vector containing the cDNA obtained previously. Plasmid extraction and purification was carried out following manufacturer instructions of the GFX Micro Plasmid Prep Kit (GE Healthcare). Purified plasmids were spectrophotometrically quantified. The forward primer included the first $\mathrm{N}$-terminal residues and the reverse primer included the last C-terminal residues of the mature protein and two stop codons. The primers were: 5'-TGTGGGGGSGTCCACAGA-3' (forward) and 5'-AAGATTGCTTACTCCTGA-3' (reverse). PCR amplification was performed in $20-\mu \mathrm{L}$ reaction volumes containing $1 \mathrm{U}$ Pfu DNA polymerase (Stratagene, Cedar Creek, TX, USA), 50 ng purified plasmid, $4 \mathrm{mM}$ dNTPs and $4 \mu \mathrm{M}$ of each primer in the PCR-buffer provided. The PCR amplification protocol 
included 30 cycles of denaturation $\left(95^{\circ} \mathrm{C}\right.$ for $\left.50 \mathrm{~s}\right)$, annealing $\left(55^{\circ} \mathrm{C}\right.$ for $\left.50 \mathrm{~s}\right)$, and extension $\left(72^{\circ} \mathrm{C}\right.$ for $50 \mathrm{~s}$ ) followed by a final extension for $8 \mathrm{~min}$ at $72^{\circ} \mathrm{C}$. The products were separated on a $1 \%$ agarose gel, stained with $0.5 \mathrm{mg} / \mathrm{mL}$ ethidium bromide, and visualized with a UV transilluminator. The amplified fragments were subcloned using $\mathrm{pTrcHis}$ TOPO TA expression kit (Invitrogen) according to manufacturer instructions. Briefly, $3 \mu \mathrm{L}$ PCR product was linked to $10 \mathrm{ng} \mathrm{pTrcHis}$ TOPO in a final reaction volume of $5 \mu \mathrm{L}$. The recombinant plasmid produced was utilized for transformation of Top10 One Shot in a proportion of 1:25 (v:v). The cells were grown in a nonselective medium and plated on ampicillin-containing medium.

\section{PCR colony and nucleotide sequencing}

Positive clones, selected by growing the transformed cells in LB medium containing 50 $\mu \mathrm{g} / \mathrm{mL}$ ampicillin, were confirmed by PCR and nucleotide sequencing using the insert-flanking pTrcHis Forward and pTrcHis Reverse primers purchased from Invitrogen. PCR was carried out using a Mastercycler ep Gradient S (Eppendorf, Hamburg, Germany), and amplicons were separated on a $1 \%$ agarose gel, stained with $0.5 \mathrm{mg} / \mathrm{mL}$ ethidium bromide, and visualized with a UV transilluminator. Plasmid extraction and purification was carried out following manufacturer instructions for the GFX Micro Plasmid Prep Kit (GE Healthcare). Nucleotide sequencing was performed using Dye terminator chemistry (DYEnamic ET Dye Terminator kit) on Mega BACE 750 DNA Analysis System (GE Healthcare). Each clone was sequenced twice with both sense and antisense insert-flanking primers and a consensus sequence was obtained.

\section{Recombinant spermadhesin expression analysis}

One positive $E$. coli Top 10 selected clone, shown by PCR amplification and nucleotide sequence to contain the correct Bdh-2 construct, was grown overnight at $37^{\circ} \mathrm{C}$ in $\mathrm{LB}$ medium containing $50 \mu \mathrm{g} / \mathrm{mL}$ ampicillin, followed by a 1:50 (v/v) dilution in the same medium. Cells were grown to an optical density of 0.6 at $600 \mathrm{~nm}$ and were induced to express $\mathrm{rBdh}-2$ by the addition of isopropyl- $\beta$-D-thiogalactoside (IPTG; USB Corporation, Cleveland, OH, USA), to final concentrations ranging from 0.1 to $2 \mathrm{mM}$. For immunoblotting analysis of successful $\mathrm{rBdh}-2$ production, cells from 1-mL aliquots of the cultures were harvested after 2,4 and $6 \mathrm{~h}$ of IPTG induction by centrifugation at $6000 \mathrm{~g}$ for $10 \mathrm{~min}$ and the pellets stored frozen at $-20^{\circ} \mathrm{C}$.

\section{Immunoblotting}

For immunoblotting detection of the rBdh-2 linked to six histidine residues (rBdh2-His 6 ), pellet samples were submitted to SDS-PAGE according to Laemmli (1970). Cells in loading buffer ( $50 \mathrm{mM}$ Tris-HCl, $\mathrm{pH} 6.8,2 \% \mathrm{SDS}, 0.1 \%$ bromophenol blue, 10\% glycerin) were boiled for $5 \mathrm{~min}$ and separated on $12.5 \%$ polyacrylamide gels. High range prestained protein ladders $14-220 \mathrm{kDa}$ (GE Healthcare) were used as molecular weight markers. SDSPAGE-separated proteins were then transferred to polyvinylidene membranes (GE Healthcare) at a constant voltage of $25 \mathrm{~V}$ at room temperature for $2 \mathrm{~h}$ using a miniVE Blot Module apparatus (GE Healthcare) and $25 \mathrm{mM}$ Tris- $\mathrm{HCl}, \mathrm{pH} 8.3,192 \mathrm{mM}$ glycine and 20\% methanol $(\mathrm{v} / \mathrm{v})$ as transfer buffer. Nonspecific binding sites were blocked by incubating the membranes with 5\% nonfat dry milk (w/v) in TTBS (100 mM Tris-HCl, pH 7.5, $150 \mathrm{mM} \mathrm{NaCl}$ and $0.1 \%$ 
Tween 20) overnight at $4^{\circ} \mathrm{C}$. Subsequently, the membranes were incubated with a 1:1500 (v/v) dilution of the monoclonal anti-polyhistidine antibody clone HIS-1 (Sigma-Aldrich, St. Louis, MO, USA) for $150 \mathrm{~min}$ at room temperature. After washing three times with TTBS, the membranes were incubated for 60 min with a 1:10,000 (v/v) dilution of anti-mouse IgG-alkaline phosphatase (Sigma-Aldrich), washed three times with TTBS and once with TBS (100 mM Tris- $\mathrm{HCl}, \mathrm{pH} 7.5,150 \mathrm{mM} \mathrm{NaCl})$. $\mathrm{rBdh}-2-\mathrm{His}_{6}$ was visualized by the addition of Sigma Fast NBT/BCIP-buffered substrate (Sigma-Aldrich) and the reaction was stopped with water.

\section{Extraction of spermadhesin $\mathrm{His}_{6}$ fusion protein}

In order to search for the putative insoluble form of rBdh-2-His, the cells obtained from $50 \mathrm{~mL}$ of culture were harvested by centrifugation at $6000 \mathrm{~g}$ for $10 \mathrm{~min}$. The pellet was suspended in $8 \mathrm{~mL}$ of native buffer ( $50 \mathrm{mM}$ sodium phosphate, $500 \mathrm{mM} \mathrm{NaCl}, \mathrm{pH} 8.0$ ) or in $8 \mathrm{~mL}$ denaturing buffer ( $8 \mathrm{M}$ urea, $20 \mathrm{mM}$ sodium phosphate, $500 \mathrm{mM} \mathrm{NaCl}, \mathrm{pH} 7.8$ ). Cells were lysed by sonication ( 5 cycles of $15 \mathrm{~s}$ sonication followed by $5 \mathrm{~s}$ rest) in an ice bath to reduce viscosity. The lysates were centrifuged at $6000 \mathrm{~g}$ for $30 \mathrm{~min}$ at $4^{\circ} \mathrm{C}$. The clear supernatant (soluble fraction) and the remaining pellet (insoluble fraction) containing inclusion bodies were collected and analyzed by the immunoblotting method as described above.

\section{Image analysis and statistics}

The image of each immunoblot membrane was recorded and the intensity of each band was assessed by densitometry using an image analysis program (ImageQuant TL 2005, Amersham Biosciences, Pittsburgh, PA, USA). Quantitative analysis of the expression of $\mathrm{rBdh}-2$ was performed by normalizing the data to the density of the band produced in the presence of 2 mM IPTG, after a 2-h induction, which was assigned a value of 1.0. The quadratic curve model was utilized to calculate the apparent molecular weight of the protein. The data are reported as means \pm SEM of at least three replicates for each assay on different membranes. The program used for statistical analysis was GraphPad InStat 3.06 (GraphPad Software, San Diego, CA, USA). Data were compared using the Tukey significant difference procedure and the statistical significance was considered at $\mathrm{P}<0.01$.

\section{RESULTS AND DISCUSSION}

In earlier studies, our group cloned and characterized cDNAs encoding the four main isoforms of buck spermadhesins, designated Bodhesin-1, -2, -3, and -4 (Melo et al., 2008, 2009). In the present study, we subcloned the cDNA of Bdh-2, which was the most similar to BSFP, previously purified from seminal plasma by Teixeira et al. (2002). We used as PCR template the clones produced by Melo et al. (2008), which contain cDNA inserts of $607 \mathrm{bp}$. In particular, the Bdh-2 cloned fragments comprised a 318-bp ORF (open reading frame) including the stop codon and a 278-bp 3'-untranslated region.

In order to subclone the Bdh-2 coding region corresponding to 105 amino acids into the pTrcHis TOPO vector, we used two primers designed to amplify only the ORF. The recombinant plasmid pTrcHis-Bdh-2 (Figure 1A) was transformed into E. coli and 19 clones were selected by growth in ampicillin-containing medium. The clones containing the construct were identified by 
PCR, using insert-flanking primers and then confirmed by nucleotide sequencing. The length of all PCR products was approximately 350 bp (Figure 1B). All clones investigated contained DNA inserts compatible with the size of the ORF of the spermadhesin Bdh-2 utilized in the present study.

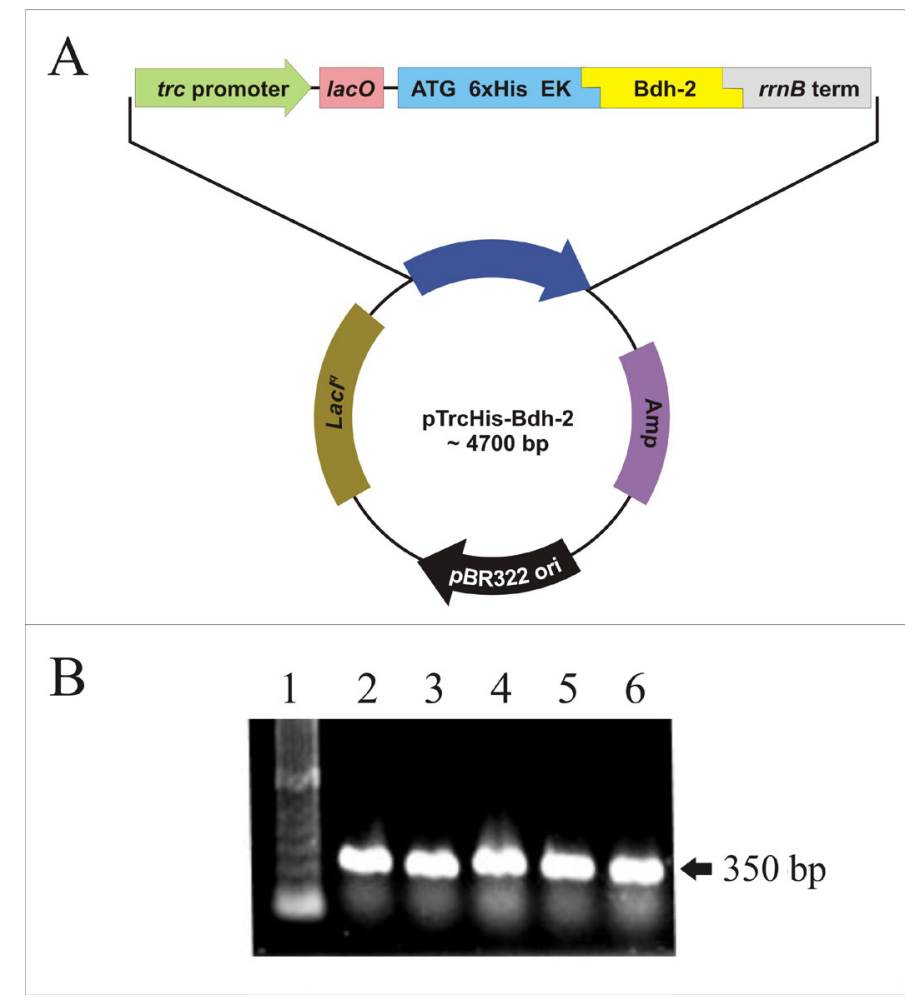

Figure 1. Construction and identification of pTrcHis-Bdh-2 prokaryotic expression vector. A. Schematic diagram of the features of pTrcHis-Bdh-2 vector. pBR322 ori = origin of replication; Amp = ampicillin resistance gene; $\mathrm{LacI}^{q}=\mathrm{lac}$ repressor gene; $l a c O=l a c$ operator; $\mathrm{ATG}=$ start codon; $6 \times \mathrm{His}=$ sequence coding for polyhistidine tag; $\mathrm{EK}=$ enterokinase cleavage site; Bdh-2 $=\mathrm{Bdh}-2 \mathrm{cDNA}$ fragment; $r r n B$ term $=$ transcription termination sequence. B. Identification of recombinant plasmid pTrcHis-Bdh-2 by polymerase chain reaction (PCR) analysis. Lane 1, High-Range Rainbow Molecular Weight Markers (GE Healthcare); lanes 2 to 6, PCR amplification products of pTrcHis-Bdh-2 using insert-flanking primers.

Based on nucleotide sequencing of the expression vectors produced, one clone was selected for expression of the recombinant protein. The cDNA and the plasmid insert-flanking regions were completely identified (Figure 2). The inserted fragment showed $100 \%$ similarity with the corresponding region of Bdh-2 cDNA previously described (GenBank accession number EF157969). Additionally, the inserted cDNA was in frame with the start codon ATG of the pTrcHis-TOPO vector. This fact ensures a correct translation and the production of a true Bdh-2 amino acid sequence. The $\mathrm{pTrcHis}-\mathrm{Bdh}-2$ vector produced encodes a polypeptide chain of 140 amino acids, of which 105 residues correspond to rBdh-2. The 35 extra amino 
acid residues are coded by the plasmid and correspond to the N-terminal end containing six histidines (6xHis) and a cleavage site for the action of the enzyme enterokinase (Figure 2).

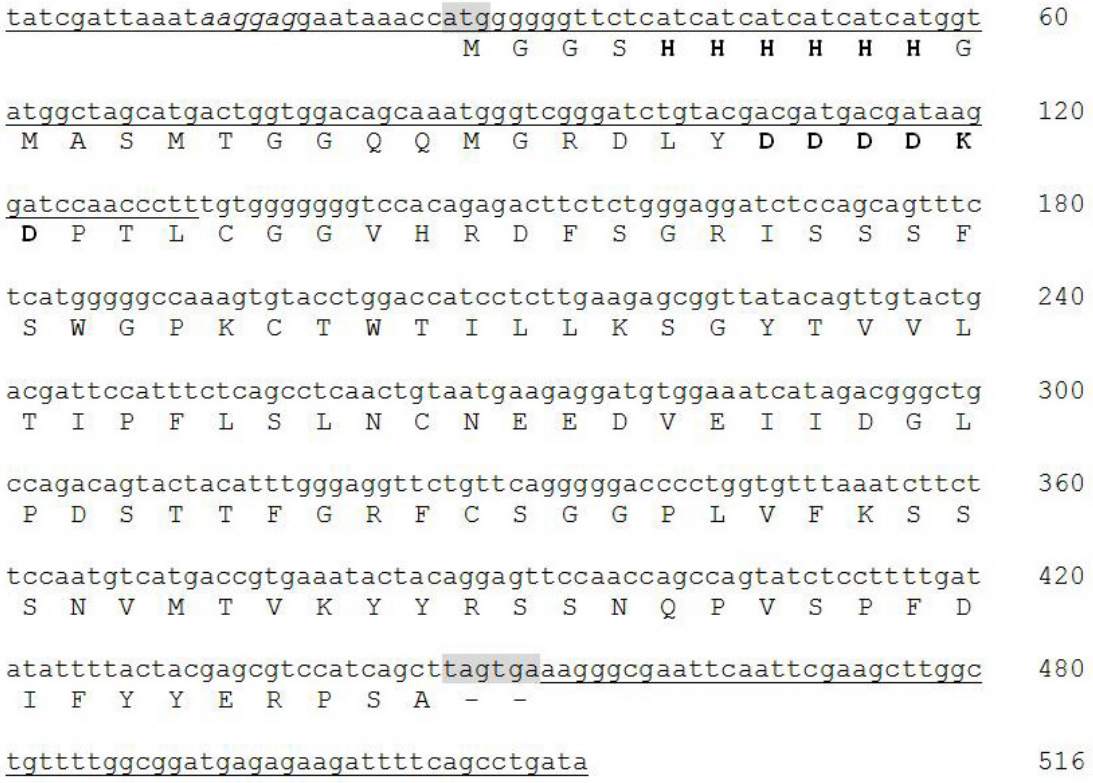

Figure 2. Nucleotide sequence of pTrcHis-Bdh-2 expression vector and translated amino acid sequence. The plasmid vector is shown by underlined letters. The start (ATG) and the two consecutive stop codons are enclosed in grey boxes. Ribosome binding site is presented in italic letters. The $6 \times \mathrm{His}$ tag and the enterokinase recognition sequence are shown in bold letters.

A number of central elements are essential in the design of recombinant expression systems (Baneyx, 1999; Jonasson et al., 2002). Recombinant expression plasmids require, among others, a strong transcriptional promoter to control high-level gene expression and a suitable repressor to minimize basal transcription in the absence of inducer. The most common inducer is the sugar molecule IPTG (Hannig and Makrides, 1998). The pTrcHis-TOPO vector is a pBR322-based plasmid containing the trc promoter, the lac operator $(\mathrm{lacO})$ and the $l a c I^{q}$ gene (Figure 1A). The lac operator is the binding site of lac repressor, which is encoded by the $\operatorname{lacI}^{q}$ gene, to provide regulated expression of the trc promoter (Jacob and Monod, 1961; Müller-Hill et al., 1968). Thus, in the absence of IPTG, lac repressor binds to the lacO sequence, repressing transcription (Jacob and Monod, 1961; Müller-Hill et al., 1968). To induce expression, IPTG is added to a final concentration of interest and the culture monitored for expression of the recombinant protein. In the present study, the expression of the spermadhesin $\mathrm{His}_{6}$ fusion protein was achieved at IPTG concentrations ranging from 0.1 to $2.0 \mathrm{mM}$ and after 2- to 6-h induction (Figure 3). The recombinant protein synthesis was monitored by SDS-PAGE under reducing conditions followed by immunoblotting using monoclonal anti-His antibody. 


\section{IPTG concentration $(\mathrm{mM})$}

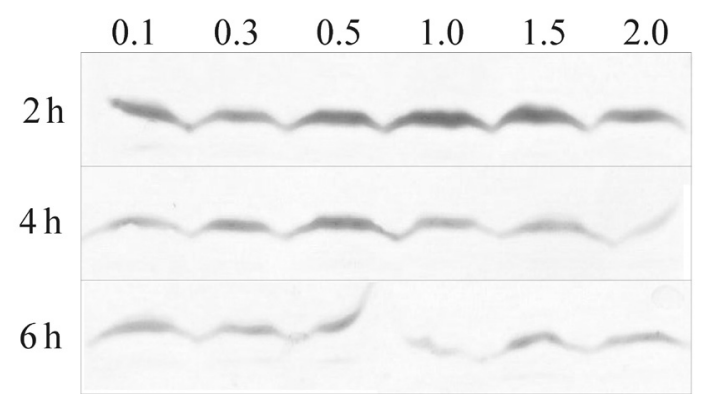

Figure 3. Expression analysis of His -fusion rBdh-2 spermadhesin in Escherichia coli. Total proteins of pTrcHisBdh-2 transformant were submitted to $12.5 \%$ SDS-PAGE and analyzed by immunoblotting using monoclonal antiHis antibody. Cell samples were collected after 2,4 or $6 \mathrm{~h}$ of isopropyl- $\beta$-D-thiogalactoside (IPTG) induction at a final concentration ranging from 0.1 to $2.0 \mathrm{mM}$.

His 6 - $\mathrm{Bdh}-2$ expression was induced at $37^{\circ} \mathrm{C}$, and the apparent molecular weight was $15.85 \pm 0.09 \mathrm{kDa}(\mathrm{N}=36)$, calculated by image analysis of membranes. This result agrees with the theoretical molecular weight of $15.5 \mathrm{kDa}$ predicted from the pTrcHis-Bdh-2 nucleotide sequence that encodes $\mathrm{rBdh}-2$ with about $12 \mathrm{kDa}$ and the artificial histidine tag with 3 to $4 \mathrm{kDa}$. Additionally, the $\mathrm{rBdh}-2$ molecular weight is in accordance with that described for all spermadhesin members, ranging from 12 to $16 \mathrm{kDa}$ (Töpfer-Petersen et al., 1998).

We also compared the relative protein productions by densitometric analysis of the intensity of each band on membrane images (Figure 4). A significantly greater production of rBdh-2 $(\mathrm{P}<0.01)$ occurred in the presence of $1.5 \mathrm{mM}$ IPTG after a 2-h induction, and with 0.3 $\mathrm{mM}$ IPTG after a 4-h culture. Among the induction times investigated, a period of $6 \mathrm{~h}$ showed the lowest levels of rBdh-2 production, where no difference was seen between the various concentrations of IPTG tested $(\mathrm{P}>0.01)$.

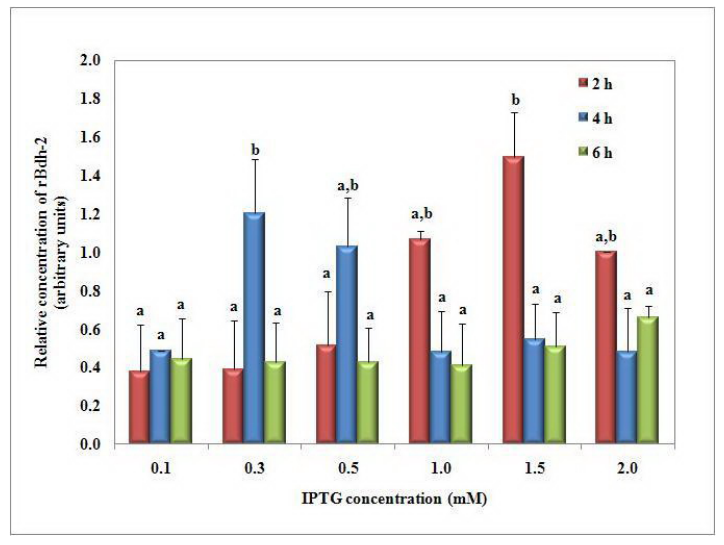

Figure 4. Effects of isopropyl- $\beta$-D-thiogalactoside (IPTG) concentration and time of induction on relative abundance of $\mathrm{rBdh}-2$ spermadhesin $\mathrm{His}_{6}$ fusion protein in Escherichia coli expression system. Bacterial samples were collected after $2 \mathrm{~h}$ (red bars), $4 \mathrm{~h}$ (blue bars) or $6 \mathrm{~h}$ (green bars) of IPTG induction at a final concentration ranging from 0.1 to $2.0 \mathrm{mM}$. Bars with different superscript letters differ significantly $(\mathrm{P}<0.01)$. 
E. coli is the preferred host for heterologous protein production for several studies. However, some proteins simply fail to be expressed in E. coli, or are expressed but in an insoluble form as inclusion bodies (Peti and Page, 2007). Inclusion bodies are a set of structurally complex aggregates often believed to occur as a stress response when recombinant protein is expressed at high rates (van den Berg et al., 1999). The insoluble recombinant protein normally enriches the inclusion bodies by $50-95 \%$ of the protein material (Carbonell and Villaverde, 2002). Rather little is known about the mechanism of inclusion body formation (Villaverde and Carrio, 2003). However, it is known that the formation of inclusion bodies in recombinant expression systems is the result of an imbalance between in vivo protein aggregation and solubilization (Jonasson et al., 2002).

In the present study, to examine the distribution of expressed $\mathrm{rBdh}-2$ protein in soluble and insoluble fractions, both the supernatant and pellet of cell lysates after sonication in native buffer were analyzed (Figure 5A). Samples were also analyzed by SDS-PAGE under reducing conditions and subsequent immunoblotting using monoclonal anti-His antibody. A single band corresponding to $\mathrm{His}_{6}-\mathrm{Bdh}-2$ was produced after IPTG induction (Figure 5A, lanes 1 and 2) and was almost insoluble in native buffer (Figure 5A, lanes 3 and 4). Thus, the synthesized rBdh-2 fusion protein was obtained largely in the insoluble fraction of the bacterial extract, as inclusion bodies. However, after cell sonication in denaturing buffer, approximately half of the total amount of rBdh-2 was dissolved (Figure 5B, lanes 3 and 4).

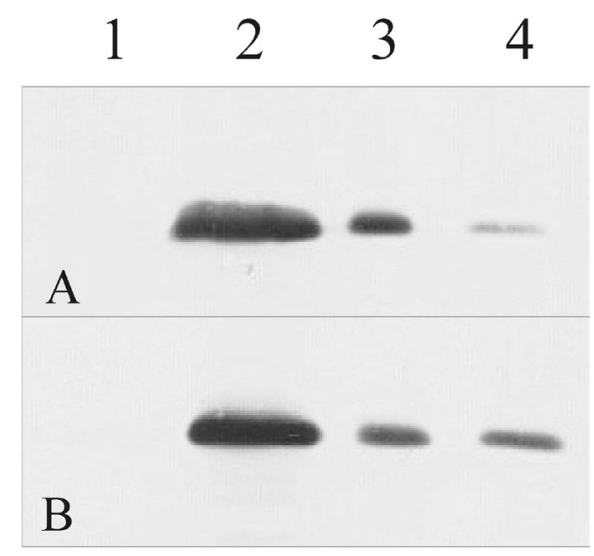

Figure 5. Extraction of $\mathrm{His}_{6}$-fusion $\mathrm{rBdh}-2$ produced in Escherichia coli with native (A) or denaturing (B) buffer. Total proteins of pTrcHis-Bdh-2 transformant were submitted to $12.5 \%$ SDS-PAGE and analyzed by immunoblotting using monoclonal anti-His antibody. Samples of bacterial culture before (lane 1) and after (lane 2) IPTG induction, as well as the insoluble (lane 3) and soluble (lane 4) fractions were used.

The prokaryotic expression system constructed in the present study allowed the efficient production of spermadhesin Bdh-2 in the insoluble form in E. coli. In addition, the maximal production of rBdh-2 is probably obtained after 2- to 4-h induction with IPTG. Thus, we believe that the longest induction period, that is $6 \mathrm{~h}$, led to the degradation of the protein expressed. This is possible because inclusion bodies are not inert aggregates but act as a transient reservoir for loosely packaged folding intermediates in vivo (Carrio and Villaverde, 2001). 
Proteases are directly involved in the in situ degradation of unfolded or misfolded inclusion body-associated polypeptides by interaction with exposed hydrophobic patches (Carbonell and Villaverde, 2002). Arrest of recombinant protein synthesis results in the efficient removal and refolding of inclusion bodies but with most protein degraded by proteases and only small fractions resisting further processing (Carrio and Villaverde, 2001).

As shown in the present assay, the inclusion body aggregates can be solubilized using detergents such as urea. Subsequently, native protein can be prepared by in vitro refolding from solubilized inclusion bodies either by dilution, dialysis or on-column refolding methods (Middelberg, 2002; Sørensen et al., 2003).

Recently, recombinant boar AQN-1 and bull aSFP spermadhesins were successfully produced in a prokaryotic system (Ekhlasi-Hundrieser et al., 2008). The cited authors demonstrated that recombinant wild-type and some mutant spermadhesins exhibited similar mannose-binding characteristics, when compared to seminal plasma-isolated ones. Similar to that study, our expression system was constructed to produce an insoluble spermadhesin $\mathrm{His}_{6}$ fusion protein in E. coli Top 10 cells. Thus, we propose that, after solubilization, $\mathrm{rBdh}-2$ keeps the same putative biological activity as the seminal plasma-isolated BSFP.

Prior to this study, expression of recombinant buck spermadhesin had never been reported. After affinity purification, the production of anti-rBdh-2 antibodies is more feasible. These antibodies will serve as a tool to access the expression level and the function of native Bdh-2 from buck seminal plasma. Additionally, the direct application of rBdhs has great potential with regard to enhancing our knowledge of buck reproductive mechanisms and further application in reproductive biotechnologies.

\section{ACKNOWLEDGMENTS}

The authors thank the following funding agencies: CNPq (Brasília, Brazil), FUNCAP (Fortaleza, Brazil) and International Foundation for Science (Stockholm, Sweden), the last through a project coordinated by Dr. D.I.A. Teixeira. J.B. Cajazeiras received a fellowship from CNPq, Dr. L.M. Melo is a fellow of the CAPES/PNPD (Brasília, Brazil) program and Drs. G. Rádis-Baptista, B.S. Cavada and V.J.F. Freitas are recipients of CNPq research scholarships. Dr. A. Leyva provided English editing of the manuscript.

\section{REFERENCES}

Baneyx F (1999). Recombinant protein expression in Escherichia coli. Curr. Opin. Biotechnol. 10: 411-421.

Bergeron A, Villemure M, Lazure C and Manjunath P (2005). Isolation and characterization of the major proteins of ram seminal plasma. Mol. Reprod. Dev. 71: 461-470.

Calvete JJ, Mann K, Schafer W, Raida M, et al. (1995). Boar spermadhesin PSP-II: location of posttranslational modifications, heterodimer formation with PSP-I glycoforms and effect of dimerization on the ligand-binding capabilities of the subunits. FEBS Lett. 365: 179-182.

Carbonell X and Villaverde A (2002). Protein aggregated into bacterial inclusion bodies does not result in protection from proteolytic digestion. Biotechnol. Lett. 24: 1939-1944.

Carrio MM and Villaverde A (2001). Protein aggregation as bacterial inclusion bodies is reversible. FEBS Lett. 489: 29-33.

Ekhlasi-Hundrieser M, Sinowatz F, Greiser De Wilke I, Waberski D, et al. (2002). Expression of spermadhesin genes in porcine male and female reproductive tracts. Mol. Reprod. Dev. 61: 32-41.

Ekhlasi-Hundrieser M, Calvete JJ, Von Rad B, Hettel C, et al. (2008). Point mutations abolishing the mannose-binding capability of boar spermadhesin AQN-1. Biochim. Biophys. Acta 1784: 856-862. 
Goulding CW and Perry LJ (2003). Protein production in Escherichia coli for structural studies by X-ray crystallography. J. Struct. Biol. 142: 133-143.

Haase B, Schlotterer C, Hundrieser ME, Kuiper H, et al. (2005). Evolution of the spermadhesin gene family. Gene 352: 20-29.

Hannig G and Makrides SC (1998). Strategies for optimizing heterologous protein expression in Escherichia coli. Trends Biotechnol. 16: 54-60.

Jacob F and Monod J (1961). Genetic regulatory mechanisms in the synthesis of proteins. J. Mol. Biol. 3: 318-356.

Jonasson P, Liljeqvist S, Nygren PA and Stahl S (2002). Genetic design for facilitated production and recovery of recombinant proteins in Escherichia coli. Biotechnol. Appl. Biochem. 35: 91-105.

Kwok SC, Yang D, Dai G, Soares MJ, et al. (1993). Molecular cloning and sequence analysis of two porcine seminal proteins, PSP-I and PSP-II: new members of the spermadhesin family. DNA Cell Biol. 12: 605-610.

Laemmli UK (1970). Cleavage of structural proteins during the assembly of the head of bacteriophage T4. Nature 227: 680-685.

Melo LM, Teixeira DI, Havt A, da Cunha RM, et al. (2008). Buck (Capra hircus) genes encode new members of the spermadhesin family. Mol. Reprod. Dev. 75: 8-16.

Melo LM, Nascimento AS, Silveira FG, Cunha RM, et al. (2009). Quantitative expression analysis of Bodhesin genes in the buck (Capra hircus) reproductive tract by real-time polymerase chain reaction (qRT-PCR). Anim. Reprod. Sci. 110: $245-255$.

Middelberg AP (2002). Preparative protein refolding. Trends Biotechnol. 20: 437-443.

Müller-Hill B, Crapo L and Gilbert W (1968). Mutants that make more lac repressor. Proc. Natl. Acad. Sci. U. S. A. 59: 1259-1264.

Peti W and Page R (2007). Strategies to maximize heterologous protein expression in Escherichia coli with minimal cost. Protein Expr. Purif. 51: 1-10.

Reinert M, Calvete JJ, Sanz L, Mann K, et al. (1996). Primary structure of stallion seminal plasma protein HSP-7, a zonapellucida-binding protein of the spermadhesin family. Eur. J. Biochem. 242: 636-640.

Sorensen HP, Sperling-Petersen HU and Mortensen KK (2003). Dialysis strategies for protein refolding: preparative streptavidin production. Protein Expr. Purif. 31: 149-154.

Tedeschi G, Oungre E, Mortarino M, Negri A, et al. (2000). Purification and primary structure of a new bovine spermadhesin. Eur. J. Biochem. 267: 6175-6179.

Teixeira DI, Cavada BS, Sampaio AH, Havt A, et al. (2002). Isolation and partial characterisation of a protein from buck seminal plasma (Capra hircus), homologous to spermadhesins. Protein Pept. Lett. 9: 331-335.

Teixeira DI, Melo LM, Gadelha CA, Cunha RM, et al. (2006). Ion-exchange chromatography used to isolate a spermadhesin-related protein from domestic goat (Capra hircus) seminal plasma. Genet. Mol. Res. 5: 79-87.

Töpfer-Petersen E, Romero A, Varela PF, Ekhlasi-Hundrieser M, et al. (1998). Spermadhesins: a new protein family. Facts, hypotheses and perspectives. Andrologia 30: 217-224.

Töpfer-Petersen E, Ekhlasi-Hundrieser M and Tsolova M (2008). Glycobiology of fertilization in the pig. Int. J. Dev. Biol. 52: 717-736.

van den Berg B, Ellis RJ and Dobson CM (1999). Effects of macromolecular crowding on protein folding and aggregation. EMBO J. 18: 6927-6933.

Villaverde A and Carrio MM (2003). Protein aggregation in recombinant bacteria: biological role of inclusion bodies. Biotechnol. Lett. 25: 1385-1395.

Wempe F, Einspanier R and Scheit KH (1992). Characterization by cDNA cloning of the mRNA of a new growth factor from bovine seminal plasma: acidic seminal fluid protein. Biochem. Biophys. Res. Commun. 183: 232-237. 